Article

\title{
Achieving Child Friendly Justice through Child Friendly Methods: Let's Start with the Right to Information
}

\author{
Helen Stalford *, Liam Cairns and Jeremy Marshall \\ * Corresponding author \\ Submitted: 16 May 2017 | Accepted: 26 July 2017 | Published: 26 September 2017
}

European Children's Rights Unit, School of Law and Social Justice, University of Liverpool, Liverpool, L69 7ZA, UK; E-Mails: stalford@liverpool.ac.uk (H.S.), liam.cairns@investinginchildren.net (L.C.), j.marshall@liverpool.ac.uk (J.M.)

\begin{abstract}
Making the justice process 'child friendly' is a key priority for the children's rights community. An abundance of commentary has been produced by the UN Committee on the Rights of the Child to highlight how justice proceedings can be made more accessible for children and, in 2010, the Council of Europe issued its comprehensive 'Guidelines on Child Friendly Justice'. Despite these efforts, children remain ill-informed, not just about the nature of justice proceedings in which they may be implicated, but about the very existence and scope of their rights and how to enforce them. Despite unequivocal acknowledgement that the availability and accessibility of information is the crucial starting point in a children's rights-based approach to dispensing justice, there has been surprisingly little attempt to scrutinise the availability, quality and accessibility of information about laws and policies affecting children. This article takes a closer look at what, exactly, 'child friendly' information means in practice. In doing so, we argue that attempts to develop child friendly information have yet to progress beyond adult-driven, largely tokenistic and superficial re-branding exercises. As such, efforts to develop child friendly resources are often of limited value in empowering young people to develop their legal literacy and realise their rights in practice. We reflect on our attempt to develop an explicitly children's rights-based approach to the development of child friendly resources with a view to enhancing their purchase. This took place in the context of a pilot project, commissioned by the Council of Europe in June 2014, to create a child friendly version of their Child Friendly Justice Guidelines.
\end{abstract}

\section{Keywords}

child friendly; information; justice; online media; participation; right to information

\section{Issue}

This article is part of the issue "Promoting Children's Participation in Research, Policy and Practice", edited by Jo Aldridge (Loughborough University, UK).

(C) 2017 by the authors; licensee Cogitatio (Lisbon, Portugal). This article is licensed under a Creative Commons Attribution 4.0 International License (CC BY).

\section{Introduction: The Right to Information as a Central Tenet of Child Friendly Justice}

'Child friendly justice' has become a familiar refrain accompanying developments in international and domestic justice processes involving children and young people. Virtually every provision of the UN Convention on the Rights of the Child 1989 (UNCRC; United Nations, 1989 ) includes at least one reference to children's rights in the context of justice proceedings, including children's right to appropriate (legal) assistance and direction (e.g., Arts. 5, 14, 22 and 37) to participate in the decisionmaking process (Arts. 9 and 12), to the avoidance of undue delay (Arts. 10 and 37), and to be protected before, during and after justice proceedings (Arts. 16, 19, 20 and 21). The UN Committee on the Rights of the Child has fleshed out what these obligations entail through a series of General Comments (detailed guidance on how to interpret and apply the substantive provisions of the UN$\mathrm{CRC}$ ) including: General Comment 12 on the right of the 
child to be heard (UN Committee on the Rights of the Child, 2009); ${ }^{1}$ General Comment No. 10 on Children's rights in juvenile justice (UN Committee on the Rights of the Child, 2007); and General Comment No. 5 on General measures of implementation for the Convention on the Rights of the Child (UN Committee on the Rights of the Child, 2003).

International support for the development of child sensitive justice processes has been further reinforced by the introduction, in 2010, of the Council of Europe Guidelines (the Guidelines) on Child Friendly Justice, developed as part of the Council of Europe's (CoE) comprehensive children's rights strategy (Council of Europe, 2016, pp. 18-19). These Guidelines were developed to enhance children's access to and treatment in the justice process. They apply to a range of justice contexts, including family, immigration, criminal justice, public administration and civil proceedings. They explain precisely how children's rights should be upheld before, during and after justice proceedings, and define child friendly justice as:

Justice systems which guarantee the respect and the effective implementation of all children's rights at the highest attainable level....It is, in particular, justice that is accessible, age appropriate, speedy, diligent, adapted to and focused on the needs and rights of the child, respecting the rights of the child including the rights to due process, to participate in and to understand the proceedings, to respect for private and family life and to integrity and dignity. (Council of Europe, 2010, para. IIc)

While it remains open to debate the extent to which these ideals have been successfully transposed into justice processes at national level, there is certainly evidence of a concerted effort in jurisdictions across the globe to accommodate more sensitively the interests and needs of children (African Child Policy Forum \& Defence for Children International, 2012; Grandjean, 2009; O’Donnell, 2009).

A central component and, one might argue, the critical starting point of child friendly justice is the provision of information. The UN Committee states as such in its General Comment 12 on the right to be heard: "Particular attention needs to be paid to the provision and delivery of child-friendly information" (UN Committee on the Rights of the Child, 2009, para. 34). Children and their representatives cannot realise their rights without reliable and accurate information not only about the content and scope of their entitlement in any given context, but about how to enforce those rights. In the same vein, the CoE Guidelines on Child friendly justice state that,

From their first involvement with the justice system or other competent authorities (such as the police, im- migration, educational, social or health care services), children and their parents should be promptly and adequately informed of their rights...and of what to expect from each stage of the proceedings. (Guideline 1)

To achieve this, the Guidelines prescribe that,

Child-friendly materials containing relevant legal information should be made available and widely distributed, and special information services for children such as specialised websites and helplines established" (Guideline 4).

Despite unequivocal acknowledgement that the availability and accessibility of information is the crucial starting point in any child rights based approach to dispensing justice, there has been surprisingly little attempt to scrutinise the availability, quality, accessibility and value of information about laws and policies affecting children. Rather, most attempts to critically engage with justice processes, even those that purport to be from a children's rights perspective, have focused on procedural and environmental factors: the conditions under and extent to which children's views are heard and taken into account by professionals/practitioners and parents (Birnbaum, Bala, \& Cyr, 2011; Brighouse, 2003; Cashmore \& Parkinson, 2008, 2009; Daly, 2017; Fortin, 2004; Leviner, 2015; Nolan, 2010); the methods by which children's best interests are assessed (Eekelaar, 2015; Mnookin, 1985; Parker, 1994; Piper, 2001); or the amenability of the physical (court) environment to children's specific interests and vulnerabilities (EU Agency for Fundamental Rights, 2017, p. 13). There has been a surprising lack of critical engagement with the actual 'triggers' of or 'gateways' to child friendly justice. By this we mean the nature, quality and relevance of information to which children have access that enables them to understand and assert their rights at various stages of the justice process. We regard this as the crucial starting point in any child rights-based approach to dispensing justice and refer to it as children's legal literacy (see also Watkins, Lai-Chong, Barwick, \& Kirk, in press). Literacy, in the conventional sense, denotes the ability to read and write. Children's experience of education, in the conventional sense, implies a heavy reliance on the acquisition of literacy skills since, without them, a child's progress within and experience of education will be limited. In the same token, a child's access to, progress within and experience of the justice process will be limited, damaging even, if they have inaccurate or insufficient knowledge and understanding of what their rights mean in practice.

With this in mind, this article takes a closer look at what, exactly, 'child friendly' information means in practice. Specifically, it will critically evaluate examples of so-called 'child friendly' versions of the law in terms of

\footnotetext{
1 "Article 12...specifies that opportunities to be heard have to be provided in particular in any judicial and administrative proceedings affecting the child....A child cannot be heard effectively where the environment is intimidating, hostile, insensitive or inappropriate for her or his age. Proceedings must be both accessible and child-appropriate." (paras. 32 and 34).
} 
how they are developed, how they are made available to children, and how they are used by children and their advocates. In doing so, we argue that attempts to develop child friendly information have yet to progress beyond largely tokenistic and superficial re-branding exercises. Rather, insofar as such attempts are routinely driven by adults and fail to engage with how children see and experience the justice process, the resulting outputs might make adults feel that they are discharging their duties but are of limited value in empowering young people to realise their rights in practice. We reflect critically on our efforts to develop an explicitly child rightsbased approach to the development of child friendly resources which started with a pilot project, funded by the $\mathrm{COE}$, to create a child friendly version of their Guidelines. The CoE were rightfully concerned that in the years following their adoption the Guidelines remain largely unknown to both professionals and children in the justice system. Inevitably, therefore, it has been difficult to discern whether they had had any positive impact at all on how justice professionals engage with children or on how children themselves experience such processes. This is perhaps not surprising; the Guidelines run to 15 pages and just under 6,000 words, including a preamble, six main sections and 83 sub-sections. With this in mind, the authors were commissioned by the CoE in 2014 to run a modest pilot project aimed at demonstrating how a child friendly version of the Guidelines could be developed in partnership with children and young people.

\section{Methodological Overview}

Our research methodology was designed with the aim of reliably gathering young people's views on all aspects of the Guidelines including their form, accessibility, clarity, meaning, and potential impact on real lives. To achieve this, the pilot was undertaken in three stages. First, we conducted a desk-based mapping and review of existing information tools relating to children's rights. Second, two groups involving a total of 11 young people between the ages of 14-18 years were recruited to act as a Reference Group in both Ireland and England, all of whom had experience of the justice process in a range of contexts (including criminal justice, child protection, education and community care, and private family proceedings). It should be noted that our hope was to develop tools that could be used by children of different ages, but particularly those who would be implicated directly in justice proceedings (typically those of aged 12 and above).

This part of the process was coordinated by Investing in Children (liC), a children's rights agency base in the northeast of England and a regular collaborator with the European Children's Rights Unit (ECRU) at the University of Liverpool. lic has a track record of successfully creating innovative ways in which children and young people, particularly those living in marginalised communities, can be supported to participate in dialogue about issues that affect them. The Youth Advocacy Project (YAP) Ireland is an liC partner. Both liC and YAP have a database of children and young people with whom they have worked and members of the Reference Group were recruited by advertising the opportunity to become involved (mainly through social media).

The Reference Group provided feedback on our methodological tools and findings as the project progressed. We were particularly keen to evaluate the clarity and accessibility of some of the existing information tools we had identified in phase 1 , as well as their relevance and use by young people to support their rights. To enable the Reference Groups to fully understand the context and aims of this project and, indeed, of the COE Guidelines, the authors provided face-to-face and online briefings. A four-minute animation was produced to support this process which was made available online so that all project participants in Ireland and the UK could refer to it at any time. ${ }^{2}$

Most importantly, the Reference Groups were tasked with recruiting other young people in their respective countries (through their existing social networks) to assist with the second aspect of the project which involved consultation with other young people about the relevance and value of the Guidelines in light of their experiences of the justice process. Mindful of the broad scope of the Guidelines, in terms of the range of judicial and administrative contexts and the range of children's rights principles reflected, we selected one specific justice context in which to locate children and young people's evaluation: the family justice process. This enabled us to involve children and young people who had been through family proceedings, i.e. either public child protection proceedings (care, fostering and adoption) or civil proceedings (divorce, custody and access), to share real life experiences and insights. We also ensured that young people who might be described as living in marginalised communities were included, notably young people in the care system, young people in trouble with police, or young people living in deprived areas. ${ }^{3}$ The Reference Group recruited a total of 58 other young people with experience of the justice system who participated by means of three 'Agenda Days' (two in the UK and one in Ireland).

An Agenda Day is a unique technique developed by IiC to create an adult-free opportunity for children and young people to consider specific issues or concerns and identify priorities and proposals for improvement. 15 to 20 young people attended each Agenda Day and discussion was facilitated by members of the Reference Group. Adults did not attend. They were asked to consider how

\footnotetext{
${ }^{2}$ The online project briefing is available on YouTube at the following link: https://www.youtube.com/watch?v=DuOV83fTf3k\&index=2\&list=PLXz7NWZi5S dKcqu4DE6m4MOEL3DqWMI9C

${ }^{3}$ We did not aim specifically to recruit children and young people with disabilities to the project; some of those who participated may well have had special educational needs, but we did not ask them to disclose such issues. The only pre-condition for their participation was that they had some experience of the family justice process.
} 
accessible the Guidelines are and to make suggestions as to how they could be made more so. They were asked to reflect specifically on how useful and relevant the Guidelines are in assisting young people who are living through justice proceedings and to make suggestions about what might need to be done to make more effective use of the Guidelines in practice. The young facilitators from the Reference Group drafted reports of the discussions at the 'Agenda Day' summarising their key findings and identifying priority areas and suggestions as to how to make the Guidelines more child-friendly. These reports were sent to the other participants for their endorsement before being made available to the researchers.

A video conference was then held to link representatives from the Reference Group and project team in England with representatives from the Reference Group and project partners in Ireland. This enabled us to exchange experiences of the Agenda Days, to tease out differences and commonalities in experiences, and to consider how the findings could be used to inform the development of some universally applicable child friendly alternatives.

The following discussion sets out the findings of this pilot which sought not only to develop a more accessible version of the Guidelines but, more broadly, to arrive at a meaningful and useful methodology for developing child friendly information in any context. Whilst the findings are of relevance to a pan-European audience, they respond very directly to cuts in legal aid in the UK ${ }^{4}$ which have impacted profoundly on the availability of legal and financial support to enable children to enforce their rights (Law Society, 2017; Office of the Children's Commissioner, 2014; UK Children's Commissioners, 2015). The increasing paucity of affordable faceto-face legal advice and support for children renders reliable, accessible and adapted information all the more essential. It also reinforces the potential value of new media-particularly the online environment-as a platform for more creative engagement with children and young people on their own terms and for the development and dissemination of legal information in genuine partnership with them.

With this in mind, the remaining discussion explores in more depth the meaning and scope of children's right to information, not only as a central tenet of child friendly justice, but as a central tenet of their right to participate in decisions that affect them. We consider how 'child friendly' information is commonly understood and packaged by reference to prominent 'child friendly' versions of law and policy. We then present our attempt to apply a children's rights-based approach to the development of child friendly information and critically consider the difference this might make to the relevance and value of those materials. The analysis points, albeit cautiously, to the role of online media, not simply as a vehicle for developing appealing resources and facilitating dissemina- tion, but as a means of shifting power dynamics in the justice process and positively exploiting children's natural capabilities to engage with and respond to digital media in a way that may far exceed normal adult capabilities.

\section{The Meaning, Scope and Importance of Children's Right to Information}

While it is somewhat pedestrian to note that information plays a central role in rendering justice processes child friendly, it is worth rehearsing precisely why this is the case. Perhaps most importantly information is an essential starting point for stimulating meaningful participation. Analysing the accessibility, quality, relevance and use of the information that children receive is a useful indicator of the participatory currency of a process. It is unsurprising, therefore, that the right to information is heavily endorsed by the CRC as one of a suite of participation rights. The freedom to "seek, receive and impart information" is an explicit component of the right to freedom of expression contained in Art. 13 UNCRC; and Art. 17 recognises the important function performed by the mass media to ensure that children have access to information and material from a diversity of national and international sources, especially those aimed at the promotion of their social, spiritual and moral well-being and physical and mental health. The availability of appropriate information is also at the heart of a range of substantive rights covered by the UNCRC, including adoption (Art. 21(a)); immigration and asylum (Art. 22(2)), health care for disabled children (Art. 23(4)); and educational and vocational training (Art. 28(d)). Without access to reliable, relevant information, children cannot meaningfully engage in any decision-making process. In the context of justice proceedings, this implies that children should have access to clear information about the nature, scope and purpose of each stage of the justice process, including how long it will take, where it will take place, why it is taking place at all, and who will be involved in the decision-making.

Unsurprisingly, the right to information headlines the 'General Elements of Child Friendly Justice' set out at the beginning of the CoE Guidelines and features heavily in the substantive provisions thereafter (no less than 23 times, in fact). Thus, we are advised that children should receive information in a manner adapted to their age and maturity, in a language that they can understand, in a gender- and culture-sensitive form (Guideline 2) and that it should be given directly to children as well as their parents and/or legal representatives (Guideline 3). Information rights also encompass the right to be protected against information or images that might be harmful to the child's welfare (Guideline 60).

Information that is designed to both equip children and young people with what they need to understand

\footnotetext{
${ }^{4}$ The Legal Aid changes came into force on 1 April 2013 by virtue of the Legal Aid Sentencing and Punishment of Offenders Act 2012 , removing from the scope of legal aid funding a range of civil and administrative issues of relevance to children, including private family law (custody and maintenance), personal injury, education, a significant proportion of immigration cases, housing and welfare benefits.
} 
the workings of the justice system and to provide them with the confidence to assert their rights will go some of the way to making their participation in justice proceedings meaningful. But the right to information demands a more nuanced understanding of the scope of the right to information and about how information should be conveyed, particularly in the context of justice proceedings.

\section{Three Distinct Layers of Information}

Child Friendly Justice means better support from adults so that young people understand different laws and how to challenge them if they are not happy with how they are treated. (Bransford, Walker, O'Connor, \& Redding, 2014, p. 6)

In terms of the scope of the right to information, the findings of this project point to three layers of information that support a genuinely participatory process, but we suggest that justice professionals' interpretations of the right to information rarely incorporates all three. We define the first layer of information as 'practical and procedural information'. The experiences discussed during the Agenda Days confirmed that, to stand any chance of making a meaningful contribution, children and young people who are involved in justice proceedings need practical information about how the legal process works, when and where it will take place, and the roles and responsibilities of the various actors, in order to understand what is happening. There are many examples of child friendly resources to explain different aspects of the justice process, many of which have been produced by specialist children's legal services. ${ }^{5}$ And yet, some of the young people involved in our project alluded to the lack of information they had received about even the most basic aspects of their case, including the time and location of hearings and the names and roles of the various adults appearing in court hearings. ${ }^{6}$

But practical information on its own is unlikely to be enough to enable children and young people to contribute meaningfully to decision-making. For children to achieve that transformational redefinition of themselves as 'competent beings' with an active stake in the justice process, it is necessary to consider information from a slightly more nuanced position. It involves a second (commonly overlooked) layer of information: what we call 'foundational rights-based information'. Children and young people need to be informed not only about what is likely to happen, but also about what should happen. For instance, children cannot object to a failure on the part of justice and welfare professionals to hear their views (for example regarding their adoption or foster placement) if they do not know that such a right exists in the first place. They need to know that they have the right to be heard in such proceedings and that what they say should be given due weight.

Acknowledging the importance of foundational rights information to children's active and meaningful participation, children's rights advocates have made some steps towards reproducing child friendly versions of existing laws, policies and guidance, particularly the UNCRC, through a variety of media. Whilst a comprehensive review of them all is beyond the scope of this paper, they generally share two key features: they repackage the text of the original document in simpler language; and they present it in a more visually appealing format (shorter, bigger text, more colourful, and often with animation).

Recognising the appeal of these types of resources, the young people involved in our project recommended that the Guidelines needed to be online and in a format young people understand, suggesting cartoons and animation, along with young people talking about the key components of child friendly justice. Some attempts have been made to achieve this already, but none of the young people we spoke to were aware of or had used them. For example, the European Union Agency for Fundamental Rights (FRA) has produced a brochure for children explaining the features of child friendly justice (EU Agency for Fundamental Rights, 2014). Published in nine languages with some illustrations, this brochure sets out key principles and procedural issues in simple terms and highlights their practical application by reference to some concrete examples. For example, it explains the 'best interests' principle as follows:

When adults make decisions about you, they should think if this decision is best for you. For example, when parents are divorcing, the decision where and who the child should live with, should be taken thinking about what is best for the child, not what is best for the mother or the father.

While the FRA's attempts to present justice concepts to children in a way that can be understood are welcome, this resource is not particularly accessible (it is buried in the FRA webpages) such that the likelihood of it being widely used by children and young people, or by professionals working with them in the justice system, is relatively slim. Indeed, not a single young person involved in our study had ever heard of the Guidelines, let alone the 'child friendly' resources aimed at explaining them, and they suspected that the justice professionals representing their interests had not heard of them either. As such, none had had the opportunity or, indeed, inclination to evaluate their experiences or assert their rights by reference to the Guidelines. Unsurprisingly, therefore, some of the young people in the project revealed alarming defi-

\footnotetext{
5 See notably the 'Lawstuff' resource developed by CORAM children's legal centre (http://lawstuff.org.uk)

${ }^{6}$ This omission is reinforced by subsequent research, funded by the European Commission in which the authors are involved, aimed at developing (in collaboration with young people) training for legal practitioners on how to adopt a child friendly approach to legal case work involving children (Training and Assistance for Legal Experts [TALE], 2015-2017).
} 
ciencies in information and knowledge about their fundamental rights in a justice context. The young participants who were in care had no idea whether they could access their own case files, or whether they had a right to maintain contact or reside with their siblings. Others questioned whether they had a right to legal aid or whether they could have a say in who they lived with following their parents' separation. Most conveyed a sense of being subjected to the justice process rather than subjects party to the process, and much of their feelings of isolation and subjugation seemed to result from a basic lack of information.

The young people thus recognised the value of and need for more guidance on the nature and scope of their rights in the context of justice proceedings and agreed that, had they been informed of the full extent of their rights as detailed in the Guidelines, their experiences of the justice process might have been more positive. Specifically, some young people involved in child protection proceedings felt that more explicit allegiance to the Guidelines might have reinforced their right to be heard in relation to decisions about their care and contact with siblings. Additionally, it would have rendered decision-makers more transparent in explaining the factors they had taken into account in determining what was in their best interests. The young people also agreed that the obligation to provide them with foundational rightsbased information is incumbent on all adults involved in the justice process, including family members, the police, social workers, lawyers and judges.

\section{Beyond Knowledge towards Understanding: Agency Asserting Information}

Despite the proliferation of online and printed resources that present children's rights in a supposedly 'child friendly' way, it remains the case that children and young people remain largely unaware of the true nature and extent of their rights. Even those children who routinely access this type of information still raise significant questions and barriers relating to their actual enforcement in practice. We think the problem partly lies in the fact that some basic messages underpinning children's rights information are commonly overlooked and even obscured: specifically, how they can and should be used to protect and enhance children's lives in real life situations. Certainly the young people involved in our study bemoaned the presentation of foundational rights-related information (including material relating to child friendly justice in a supposedly child friendly format) in largely abstract terms, detached from the specific realities of the processes and decisions confronting them. Our review of the materials supported this criticism: while many of the existing child friendly versions are appealing visually, they still present rights in relatively abstract terms. In other words, they focus largely on providing children and young people with information about their rights, but they stop short of really enabling children (and, indeed their adult representatives) to understand how these rights might be applied to their specific situation. With this in mind, while we acknowledge that translating children's rights into simple language and presenting them in an appealing format are important, they are just two (relatively superficial components) that need to be present if abstract principles are to be made more relevant to children. Beyond this, the challenge, is to provide information (and support) that will provide children and young people with the reassurance they need in order to be able to insist that their voices are heard. It is at this point that the right to information is understood not merely as conveying facts to the child, but as a process of contextualising that information, presenting genuine choices, defining what support is available to enable the child to exercise those choices, calibrating expectations in the light of other factors that influence decisions about the child, and presenting realistic and clear projections as to what outcomes might arise from different courses of action.

This defines what we see as a vital third layer of information rights: what we call 'agency asserting information'. This is where the process of providing information transmutes into a space and opportunity for the child to use that information in a way that enables them to assert their rights or, as Roger Smith puts is, to become "necessary and active agents in making justice, regardless of whether they are offenders, victims, both or neither" (Smith, 2011, p. 252). It is at this stage that we start to value and use information as a critical gateway to participation and as an essential ingredient in creating a child friendly justice system; participation both depends upon and facilitates children's understanding of the information they receive and the processes they are going through and, in turn, enables them to have a meaningful stake in any decisions involved. However, this is not straightforward. Evidence from other areas of practice such as medicine, social work and education would indicate that, even when the legislative and policy requirements to listen to and take into account children's views are clear, efforts to achieve this are often tokenistic, largely because of the type of information given to children and the lazy methods and belated points at which it is provided. Indeed, a number of commentators in the UK and Europe have suggested that the priority is to be seen to be promoting participation rather than promoting participation per se (Cairns, 2006; Crimmens, 2005; Henricson \& Bainham, 2005; Mori, 2005). As far as the vital ingredient of information is concerned, this can become a mechanistic, largely unilateral process with the adult passing information onto the child about particular aspects of their case (perhaps in the form of a leaflet, but more commonly in a letter, a text message, phone call, or a face-to-face meeting), and the child passively receiving that information, but with limited opportunity to clarify how they go about actually using that information in a way that might respond to their specific needs and desires. 
This perpetuates what has become an established default position within many of the institutions (justicerelated and otherwise) concerned with children and young people: that decisions-particularly those of a complex or sensitive nature-are best left to the adults. In other words, adults are presumed to be 'better informed'. This neglects to consider that, in the absence of regular knowledge (or information) exchange with the child, adults may be as ill-informed as the child insofar as they are likely to have limited information as to what the child actually knows and understands, what they really need, and what they really want. Orama, for example, observes that "adult professionals tend to take for granted that they know what is in the best interest of children, often without even asking the children concerned" (Orama, 2009). This is supported by the burgeoning contemporary research on the justice process which points to a stubborn tendency on the part of adults (particularly justice professionals) to "make decisions on behalf of children without any reference to children's knowledge, experience or preferences" (Lansdown \& O'Kane, 2014; Daly, 2017; Emerson, Lloyd, Lundy, Orr, \& Weaver, 2014).

\section{Towards a Child Rights-Based Approach to Developing Child Friendly Resources: Five Key Components}

Informed by the findings of the project and the feedback from the young people, we identified five components that should be present if an information resource is to be genuinely child friendly. We attempted to test these by developing our own a child friendly version of the Guidelines. Ultimately, we wanted to move beyond merely re-branding content defined by adults or simply re-presenting the text in simpler language or in a more colourful format. The five suggested components are as follows:

First, children and young people's views and lived experiences should be the starting point for developing the resource. This ensures that the child friendly resource responds to children's perspectives and experiences in a meaningful way, and maximises the likelihood of children engaging with them. One of the fundamental limitations that we identified in existing models of child friendly information is that they were developed almost exclusively by adults for children; there is very little evidence of any attempts to engage with children directly in the process of developing the resources. The extension of participation debates beyond the actual substance and process of decision-making to actual research methodologies is nothing new; there is a wealth of literature exploring the ideological, ethical and practical aspects of participatory methods as a means of achieving participatory outcomes, including in a justice context. This intelligence, however, has yet to permeate efforts to develop child friendly versions of law and policy. ${ }^{7}$ This omission is significant for two reasons: first of all, it belies the wisdom that direct engagement with children in all aspects of research and human rights education generates more relevant, accurate and meaningful outputs; and secondly, it creates an artificial and unhelpful distance or distinction between the delivery of information about children's rights on the one hand, and the process of enforcing those rights on the other. In reality, both are inextricably linked. The chances of enabling children to understand the substance and scope of their rights are much greater if that information is framed in a way that responds very directly and deliberately to children's lived experiences and desired modes of communication.

Second, the resource should be easy to follow. The young people identified as a priority the use of language and terminology that they can understand, ideally supported by images that correspond closely with the text. The child friendly resource should not try to capture all of the detail of the original text; instead it has to highlight the key points that will be most relevant and useful to children and young people. Many of the young people with whom we have engaged in more recent work on child friendly justice (Stalford et al. (TALE), 2015-2017) reinforce the point that they, like adults, will rarely absorb or even read or listen to long-winded information resources, no matter how appealing their presentation. The young people engaged in our study mined from the 83 Guidelines just three issues that they felt were instrumental to achieving child friendly justice: the provision of clear, reliable and useful information at all stages of the process; specialist training and awareness-raising among justice professionals as to the mechanisms that need to be put in place to achieve child friendly justice; and the right to have a say in decisions that affect them.

Third, the resource should focus on facilitating understanding, rather than just conveying information. In addition to using simpler language, a child friendly resource needs to be designed in a way that not only informs children and young people about their rights (foundational rights information), but that enables them to appreciate and reflect upon how and when they apply in practice (agency asserting information). This points to the need to use child friendly resources not simply as an end in themselves (job done!) but as a tool for use by practitioners and other adults in face-to-face meetings with children and young people, accompanied by ongoing sign-posting to other relevant services and information, depending on the nature of the child's legal query. In other words, to achieve true understanding and to support agency, a child friendly resource has to be relevant to children and young people's lives and to respond to the reality of children's everyday experiences of the justice process if it is to move beyond abstract information. The best way of achieving this is to illustrate specific points by reference

\footnotetext{
${ }^{7}$ At the time of writing, the authors are aware of the development of a (as yet unpublished) child friendly version of the Council of Europe's Convention on Protection of Children against Sexual Exploitation and Sexual Abuse by the Centre for Children's Rights, Queen's University Belfast, in partnership with children and young people (Council of Europe, 2007).
} 
to concrete examples, drawing on children's real life experiences of the issues covered by the law, policy or guidance. For instance, a resource telling children that they have a right to have a say in decisions that affect them in relation to contact or residence with their parents who are separating should be accompanied by specific examples as to how a child goes about asserting this in practice: who they should speak to and when; how much influence that may have on the decision ultimately made; and whether/how they go about complaining if they feel their views have not been heard or taken into account.

Fourth, a child friendly resource has to be appealing, requiring presentation in a format or range of formats that children will want to use. They should not be too lengthy or complicated and the amount of text used should be kept to a minimum (we have heard anecdotally that the average attention span of an online viewer is about 90-120 seconds!). Key points or words should be emphasised through repetition and, in an online context, supported by voice-over, images, animations or sound effects, whilst avoiding the temptation to over-clutter resources with too many gimmicks. We would therefore recommend that an online child friendly resource should last no more than 60-90 seconds and that any printed versions should be equally succinct.

Fifth, to ensure that the resource reaches the greatest number of children across the greatest range of contexts (age, region, culture etc.), it should be immediately available, preferably online, but supported by other media (ex. printed leaflets and posters etc). It should ideally be accessible through online sites visited routinely by children and young people (such as YouTube, Facebook or other social networking media), and integrated into practitioners' training programmes and everyday practice resources. Of course, in a rapidly changing and competitive technological environment, children are accustomed to engaging with graphically sophisticated resources. As such, there is a danger that any online models (including our own, developed on a shoe-string budget) become quickly dated and, consequently, have only a short-lived appeal to young people. Notwithstanding such constraints, we end our discussion with a note on the value of online media in achieving child friendly justice, since this was highlighted by the young people as a particularly familiar means of receiving and sharing information.

\section{An Attempt to Develop a Child Friendly Version of the Child Friendly Justice Guidelines Using Online Media}

One of the key findings of our research is that young people are heavily inclined towards using the internet to search for advice on legal questions and that they endorse the use of the internet to promote access to that information amongst their peers. As such, the final stage of our project involved the development of some pilot, child friendly alternatives of the Child Friendly Justice Guidelines, using basic animation technology and the online platform, YouTube. We developed three animations, narrated by members of our Reference Group, that responded to each of the priorities noted earlier that the children teased out of their reading of the Child Friendly Justice Guidelines: the right to information; the right to participate in decisions; and the importance of practitioner training. 8

We emphasise the participatory currency of social media and online technology in the context of developing child friendly justice information for a number of reasons. First, it has a cultural appeal: the internet is now embedded in our culture and is the key way in which we access information, including information about our legal rights. This is becoming particularly important in legal areas (such as private family law) that have been subject to significant cuts in legal aid provision such that face-toface legal advice and representation is gradually being replaced by online self-help guides (Rodgers, Trinder, \& Williams, 2015). The practical appeal is also evident, insofar as costs (particularly relating to dissemination) can be contained, whilst also wide and rapid. Perhaps most importantly for our purposes, however, is the fact that online information resources have an ideological appeal, potentially advancing children's participation above and beyond many other methods of engaging children. This is because children, as natives of this environment, can be engaged in a more creative and intensive way, not simply as recipients of the information it hosts, but as active co-creators. In that sense, developing online information resources flips the power dynamic, with children leading the way in supporting adults (more likely to be internet 'immigrants' than natives) to convey information rather than the other way round (Prensky, 2001). While the notion that the digital native generation are digitally literate is highly contested (Livingstone \& Brake, 2010) there is at least strong evidence that the internet generation has a preference and desire to communicate and locate information on the web. ${ }^{9}$ For commentators like Prensky, efforts to provide information through this media demands two things: an acknowledgement that we, as adults, do not know everything (or, indeed, that we may know very little), particularly when it comes to online engagement; and an openness to recruiting the views and experience of young people from the outset.

While the dissemination of legal advice and other information via the web is taken for granted by many organisations, the observations of the young people in our project highlighted the nuanced differences between young people's and adults' perceptions of the best approach to online information dissemination. Key points raised by the Reference Groups included: a desire for on-

\footnotetext{
${ }^{8}$ The animations and project documentary can be viewed at: https://www.youtube.com/playlist?list=PLXz7NWZi5SdKcqu4DE6m4MOEL3DqWMI9C

9 There is insufficient scope in this paper to explore the risks associated with young people's use of online media but we suggest that supported use of reliable online information materials that have been developed through rigorous, participatory methods should be encouraged.
} 
line advice in a format that was engaging, easy to understand, and relevant to the young people's needs; endorsement of social media platforms as effective mechanisms for both locating and for actively sharing relevant legal advice; a desire for online resources that could be accessed by social workers and other justice professionals acting in the role of advisors as well as by children themselves in order to provide a quality control mechanism for those types of advisors; the value of commenting and discussion tools within some social media platforms to provide users with a Q\&A mechanism; and the importance of maintaining avenues through which legal advice could be obtained other than online, for example, through lawyers, social workers and police who have received training in child friendly justice.

Participants did not, therefore, anticipate that social media and the web would fulfil all of their legal advice needs, or that social media would be a reliable option for all young people. Indeed, for information to be truly 'agency asserting', it has to be adaptable to the specific context and concerns of individual children or communities rather than represent or reinforce particular stereotypes. Face-to-face support and ongoing information provided (by text, phone or other digital media) in a more responsive way by practitioners or their peers as concerns and opportunities arise remain critical, therefore. Work by Roe and Livingstone further supports the need for this more nuanced understanding of how, why and, indeed, whether children and young people access information online. What emerges from Roe's work is the distinct difference in media consumption between young people based on gender, education, socioeconomic status, family and country of residence (Roe, 2000). ${ }^{10}$ Moreover, Livingstone's research argues that the notion of young people as simple consumers of online media is too simplistic (Livingstone, 1998). Online media consumption, she argues, has to be understood as part of young people's active participation within their peer culture and not as a result of their passive absorption of broadcasting.

These same points were echoed by the young people involved in our pilot and, indeed, in our subsequent work (Stalford et al, (TALE) 2015-17). They were keenly aware of the viral marketing potential of social media, a characteristic which has been acknowledged by policy makers in different sectors. This, in turn, reinforces the need to focus more strategically, not just on the content and format of online legal information, but on how young people can be instrumental in its dissemination:

Many public sector and non-governmental organisations, from educators to child welfare workers to activist movements hope that through social networking services they can address young people on their own terms, putting the potential of viral marketing to positive use." (Livingstone \& Brake, 2010, p. 75)

\footnotetext{
$\overline{10}$ There was insufficient scope to explore these issues in our pilot.
}

In the same token, the young people supported approaches to social media use that are more sophisticated, more diverse, and more central to their legal advice needs than we currently see used in practice. But the fact that such information is developed by adults, in response to adult-determined preconceptions and priorities, fundamentally limits the potential appeal and impact of the information. Donnelly and Kilkelly (2011) discuss this problem in the context of information available to young people about healthcare. Specifically, they contend that by excluding young people from the very process of developing healthcare information, it effectively polices young people's access to the full range of information that they need. This, they argue, inevitably limits young people's ability to participate meaningfully in health care decision making because the information they receive is only partially relevant and useful to them. The problem of gatekeepers frustrating effective participation by limiting information in this way applies equally to decision making in a justice context.

Social media offers a positive (albeit partial) solution to those issues due to its power to present information in ways that support searching and sharing and which usually positively promote comment, correction and criticism. But this is a double-edged sword: whilst social media sites like Facebook, YouTube and Twitter may present information for public view and public scrutiny, in the context of legal advice provision (as well as many other areas such as health advice) the public scrutiny of these sites may not be adequate to ensure that content presents a true and reliable picture of the law. Indeed, the commenting and discussion function within social media sites may play a more valuable role in developing an authentic discourse between users that reinforces the law's relevance to young people's lives rather than its legal accuracy.

\section{Conclusion}

Efforts to highlight the value of achieving children's meaningful participation in decision-making continue to dovetail with efforts to render the justice process more child friendly. But both campaigns, we argue, have largely failed to scrutinise the currency of children's right to information as an instrumental component. Information is the life-blood of participation, but we need to substantially shift the way in which we think about and deal with it. Fulfilling the right to information has to progress beyond merely providing young people with practical and procedural facts (the first layer), and even beyond informing them about the nature and scope of their fundamental rights in relation to particular aspects of the justice process (the second layer). Information has to be reinforced, repeated and refined as the process unfolds so that young people know exactly how they can implement their rights. They need to know who has the authority, experience and knowledge to address their 
concerns appropriately and how to access them. Importantly, the information they receive should be provided in a way that gives them confidence that their contribution will be welcomed and valued by a child friendly justice system and that any failure to do so is an injustice that should be contested. In short, the information has to have the potential to lead to a truly transformative change in the way children and young people experience the justice process.

The project described above represents an attempt to develop some tools in partnership with children that will assist in achieving this, although we acknowledge its limitations. Our animations are the product of a modest pilot; rather than promoting these as by any means a definitive model, the aim of our study and this paper has been to highlight the value of online technology and participatory methods as a vehicle for achieving child friendly information. We did not consciously recruit children with disabilities or children from minority ethnic or non-English speaking backgrounds. As such, our project does not interrogate how legal information should be adapted or presented to render it accessible to children with different impairments or levels of linguistic ability. Nor did we have the scope to explore fully how to engage children in disseminating child friendly information. That said, as the appetite for online legal advice and information grows, and as cuts in legal aid for children persists, there has never been a better time for innovation in this regard.

\section{Acknowledgments}

We would like to express out thanks to the 58 children and young people in England the Republic of Ireland who took part in the project that underpins this paper, and to the Council of Europe for funding it. We are grateful also to the anonymous reviewers for their feedback.

\section{Conflict of Interests}

The authors declare no conflict of interests.

\section{References}

African Child Policy Forum, \& Defence for Children International. (2012). Achieving child friendly justice in Africa. Retrieved from http://www.african childforum.org/clr/Harmonisation\%20of\%20Laws\% 20in\%20Africa/Publications/supplementary-acpf-jus tice_en.pdf

Rodgers, B., Trinder, L., \& Williams, T. (2015). Towards a family justice observatory to improve the generation and application of research. London: Nuffield Foundation.

Birnbaum, R., Bala, N., \& Cyr, F. (2011). Children's experiences with family justice professionals in Ontario and Ohio. International Journal of Law, Policy and the Family, 25(3), 398-422.
Bransford, K., Walker, J., O'Connor, J., \& Redding, S. (2014). Agenda day report of the UK young persons reference group on the Council of Europe child friendly justice guidelines.

Brighouse, H. (2003). How should children be heard? Arizona Law Review, 45(3), 691-711.

Cairns, L. (2006). Participation with purpose. In E. K. M. Tisdall, J. M. Davis, M. Hill, \& A. Prout (Eds.), Children, young people and social inclusion: Participation for what? Policy Press.

Cashmore, J., \& Parkinson, P. (2008). Children's and parents' perceptions on children's participation in decision making after parental separation and divorce. Family Court Review, 46(1), 91-104.

Cashmore, J., \& Parkinson, P. (2009). Children's participation in family law disputes: The views of children, parents, lawyers and counsellors. Family Matters, 82, 15-21.

Council of Europe. (2007). Convention on the Protection of Children against Sexual Exploitation and Sexual Abuse (CETS No. 201). Strasbourg: Council of Europe.

Council of Europe. (2010). Guidelines of the Committee of Ministers of the Council of Europe on child friendly justice. Strasbourg: Council of Europe.

Council of Europe. (2016). Strategy for the rights of the child (2016-2021). Strasbourg: Council of Europe.

Crimmens, D. (2005) The role of government in promoting youth participation in England. In D. Crimmens \& A. West (Eds.), Having their say. Young people and participation: European experiences. Lincoln: Russell House Publishing.

Daly, A. (2017). Children, autonomy and the courts: Beyond the right to be heard. Nijhoff: Brill.

Donnelly, M., \& Kilkelly, U. (2011). Child-friendly healthcare: Delivering on the right to be heard. Medical Law Review, 19(1), 27-54.

Eekelaar, J. M. (2015). The role of the best interests principle in decisions affecting children and decisions about children. International Journal of Children's Rights, 23(1), 3-26.

Emerson, L., Lloyd, K., Lundy, L., Orr, K., \& Weaver, E. (2014). The legal needs of children and young people in Northern Ireland: the views of young people and adult stakeholders. Queens University Belfast.

EU Agency for Fundamental Rights. (2014). FRA brochure explains child-friendly justice to children. Retrieved from http://fra.europa.eu/en/news/2014/fra-bro chure-explains-child-friendly-justice-children

EU Agency for Fundamental Rights. (2017). Child-friendly justice: Perspectives and experiences of children involved in judicial proceedings as victims, witnesses or parties in nine EU Member States. Strasbourg: FRA.

Fortin, J. (2004). Children's rights: Are the courts now taking them more seriously? Kings College Law Journal, 15(2), 253-272.

Grandjean, A. (2009). No rights without accountability: Promoting access to justice for children. Legal Empowerment Working Papers No. 10. 
Henricson, C., \& Bainham, A. (2005). The child and family policy divide: Tensions, convergence and rights. York: Joseph Rowntree Foundation.

Landsown, G., \& O'Kane, C. (2014). A toolkit for monitoring and evaluating children's participation. London: Save the Children.

Law Society. (2017). Access denied? LASPO four years on: A Law Society review. London: Law Society of England and Wales.

Leviner, P. (2015). The right to a fair trial from a child's perspective: Reflections from a comparative analysis of two child protection systems. In S. Mahmoudi, P. Leviner, A. Kaldal, \& K. Lainpelto (Eds.), Child-friendly justice: A quarter of a century of the UN convention on the rights of the child. Leiden: Brill.

Livingstone, S. (1998). A comparative approach to young people's changing media environment in Europe. European Journal of Communication, 13(4), 435-456.

Livingstone, S., \& Brake, S. (2010). On the rapid rise of social networking sites: New findings and policy implications. Children \& Society, 24(1), 75-83.

Mnookin, R. (1985). In the interests of children: Advocacy, law reform and public policy. New York: WH Freeman.

Mori, L. (2005). Young people as outsiders: The Italian process of youth inclusion. In D. Crimmens \& A. West (Eds.), Having their say. Young people and participation: European experiences. Lincoln: Russell House Publishing.

Nolan, A. (2010). The child as "democratic citizen": Challenging the "participation gap". Public Law, 4, 767-782.

O'Donnell, D. (2009). The rights of children to be heard: children's rights to have their views taken into account and to participate in legal and administrative proceedings. UNICEF Innocenti Working Paper No. 4.

Office of the Children's Commissioner. (2014). Legal aid changes since April 2013-Child Rights Impact Assessment.
Orama, K. (2009). Child-led organisations and the role of adult professionals: A quest for dialogue. Turku: Institute for Human Rights, Åbo Akademi University.

Parker, S. (1994). The best interests of the childPrinciples and problems. International Journal of Law and the Family, 8(1), 26-41.

Piper, C. (2001). Assumptions about children's best interests. Journal of Social Welfare and Family Law, 22(3), 261-276.

Prensky, M. (2001). Digital natives, digital immigrants. On the Horizon, 9(5), 1-6.

Roe, K. (2000). Adolescents' media use: A European view. Journal of Adolescent Health, 27(2), 15-21.

Smith, R. (2011). Doing justice to young people: Youth crime and social justice. Oxford: Willan Publishing.

Stalford, H., Cairns, L., Marshall, J. and Woodhouse, S. (2015-17) T.A.L.E. (Training Activities for Legal Experts on children rights) European Commission, EU Grant Agreement JUST/2014/RCHI/AG/PROF/7052.

UK Children's Commissioners. (2015). UN Committee on the rights of the child, examination of the fifth periodic report of the United Kingdom of Great Britain and Northern Ireland.

United Nations. (1989). United Nations Convention on the Rights of the Child. Geneva: United Nations.

UN Committee on the Rights of the Child. (2003). General Comment No. 5 on General measures of implementation for the Convention on the Rights of the Child. Geneva: United Nations.

UN Committee on the Rights of the Child. (2007). General Comment No. 10 on Children's rights in juvenile justice. Geneva: United Nations.

UN Committee on the Rights of the Child. (2009). General Comment No. 12 on the right of the child to be heard. Geneva: United Nations.

Watkins, D., Lai-Chong, E., Barwick, J., and Kirk, J. (in press). Exploring children's understanding of the law in their everyday lives. Legal Studies.

\section{About the Authors}

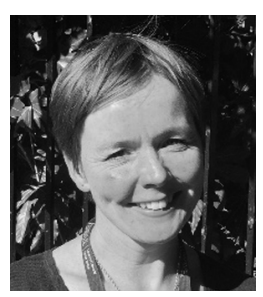

Helen Stalford is Professor of Law and Director of the European Children's Rights Unit at the School of Law and Social Justice, University of Liverpool. She has researched and published widely on children's rights in a European context and has a particular interest in how children's rights can be brought to bear on the justice process.

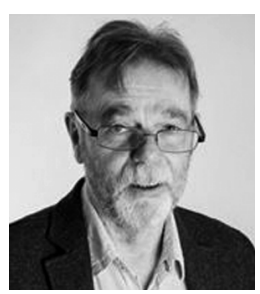

Liam Cairns is Co-Director of Investing in Children, a Community interest company based in Co. Durham that specialises in participatory methods and supports children and young people in enforcing their rights. Prior to joining Investing in Children, he spent over 20 years working with children, young people and their families in a variety of social work posts, in different local authorities in Scotland and the north of England. He is also an Honorary Research Fellow with the European Children's Rights Unit. 


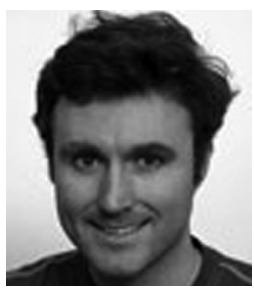

Jeremy Marshall is a Lecturer in law and E-Learning Co-Ordinator for the School of Law and Social Justice at the University of Liverpool. He has a particular expertise in developing web-based and social media tools to improve access to justice for young people who would not otherwise receive reliable and timely legal advice. 